\title{
Walter Randolph Chitwood, Jr, MD: 2020 Recipient of the American Association for Thoracic Surgery Scientific Achievement Award
}

\section{James L. Cox, MD}

In 1974, Richard Nixon resigned as president of the United States, Isabel (Evita) Peron was sworn in as the first female President of Argentina, Muhammed Ali rope-a-doped George Forman in Zaire's Rumble in the Jungle, Patty Hearst was still on the run, and Ranny Chitwood entered the Duke University Surgical Training Program under the leadership of the legendary David C. Sabiston, Jr. It was the beginning of Ranny's infamous decade with Dave (1974-1984) and it would be the middle decade of Dr Sabiston's 30-year tenure as the chair of surgery at Duke (19641994).

Ranny (NOT Randy!) was entering what had already become a storied residency program that included 3 future American Association for Thoracic Surgeons (AATS) presidents, future presidents of the American Surgical, the Southern Surgical, and the Southern Thoracic, a future chair and a future executive director of the American Board of Thoracic Surgery, a future chair of the Thoracic Surgery Residency Review Committee, numerous future chairs of surgery and major specialty divisions, a recipient of the AATS Scientific Achievement Award (other than himself), and a recipient of the Distinguished Scientist Awards from the AATS, the Society of Thoracic Surgeons (STS), and the American College of Surgeons, not to mention a resident who would later become the first person to successfully implant an artificial heart in a human being. Those Duke surgical residents included English majors from Yale; scholarship athletes from 4 major Division 1 universities; and people who had spent the Vietnam war at the National Institutes of Health, in an evac hospital near the front lines, and 2 who spent their time in the air as marine fighter pilots. It was indeed an eclectic group of young people with a wide variety of life experiences and they were among the

\footnotetext{
From the Division of Cardiac Surgery, Feinberg School of Medicine and the Bluhm Cardiovascular Institute, Northwestern University, Chicago, Ill.

Disclosures: The author reported no conflicts of interest.

The Journal policy requires editors and reviewers to disclose conflicts of interest and to decline handling or reviewing manuscripts for which they may have a conflict of interest. The editors and reviewers of this article have no conflicts of interest.

Received for publication June 29, 2020; revisions received June 29, 2020; accepted for publication June 29, 2020; available ahead of print Aug 13, 2020.

Address for reprints: James L. Cox, MD, Division of Cardiac Surgery, Feinberg School of Medicine, Northwestern University Medical Group, 676 N Saint Clair St, Arkes Pavilion, Suite 730, Chicago, IL 60611 (E-mail: james.cox@nm.org). J Thorac Cardiovasc Surg 2021;161:725-7 $0022-5223 / \$ 36.00$

Copyright $(2020$ Published by Elsevier Inc. on behalf of The American Association for Thoracic Surgery

https://doi.org/10.1016/j.jtcvs.2020.06.149
}

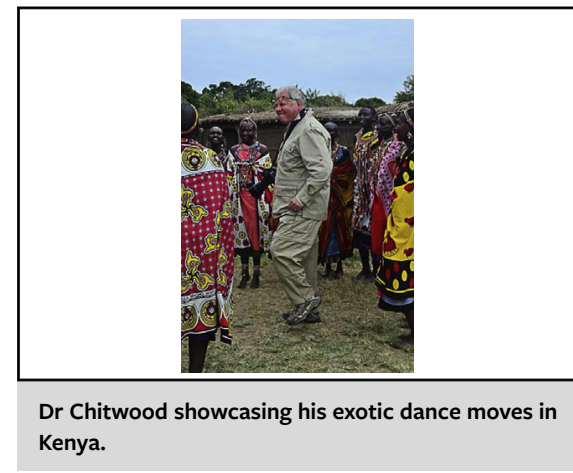

CENTRAL MESSAGE

Good guys can finish first after all!

most competitive and accomplished young people on the planet. In fact, many years later, 1 of those former residents commented, "Dr Sabiston was a master at making silk purses out of silk purses," although we all knew that The Man was much, much more than that! Despite being challenged to distinguish himself amongst such a formidable array of talented and competitive peers who were already thriving in the unfathomably brutal work environment of the Duke surgical training program, Ranny Chitwood proved himself to be among the very best to ever complete that program. And despite his multiple talents and numerous accomplishments, his highly competitive peers absolutely adored him.

Dr Chitwood was the son, of the son, of Virginia and Maryland surgeons whose family roots have been traced back to 1600s Virginia and even before that to their native England. He attended Hampden-Sydney College in Virginia, the 10th oldest college in the United States (established 1775), and then the University of Virginia Medical School. During his surgical residency at Duke, Ranny was known as an extremely bright, hard-working, and talented surgeon who was always reliable not because of the externally imposed demands but because of his own personal standards. When a new professor from an Ivy League school joined the Duke faculty, he was apparently unaware of the standards that Duke surgical residents held themselves to and his first senior resident happened to be Ranny 
Chitwood. He berated Ranny unmercifully every day until Ranny had finally had enough. "Why are you on my case all the time?" Ranny asked. The new professor answered, "I'm just trying to tighten you up!" Ranny responded, "I was BORN tight!" He was indeed born tight, and that's a reason he was such an outstanding surgical resident and why he later became one of the world's most respected and admired cardiac surgeons.

What took his peers a little longer to learn was that in addition to being a superb surgical resident, Ranny was also a master ham radio operator, a world-class photographer, an avid collector of antiquarian medical bibliophilia (old medical books), and an excellent fisherman (well, more on that later). He still operates his sophisticated ham radio system, has an incomparable library of rare medical and surgical books, has traveled all over the world on photographic forays, including 2 separate photo safaris to Kenya (Figure 1), and he still fishes (Figure 2). One of his photographic hobbies for many years has been to shoot and then greatly enlarge close-up photos of the most famous surgeons of the era. The basement in Ranny's home looks like a museum with artifacts like an original Laennec stethoscope, surgical tools, and other artifacts from centuries past and of course, his beloved albums of professional-level photographs of famous surgeons.

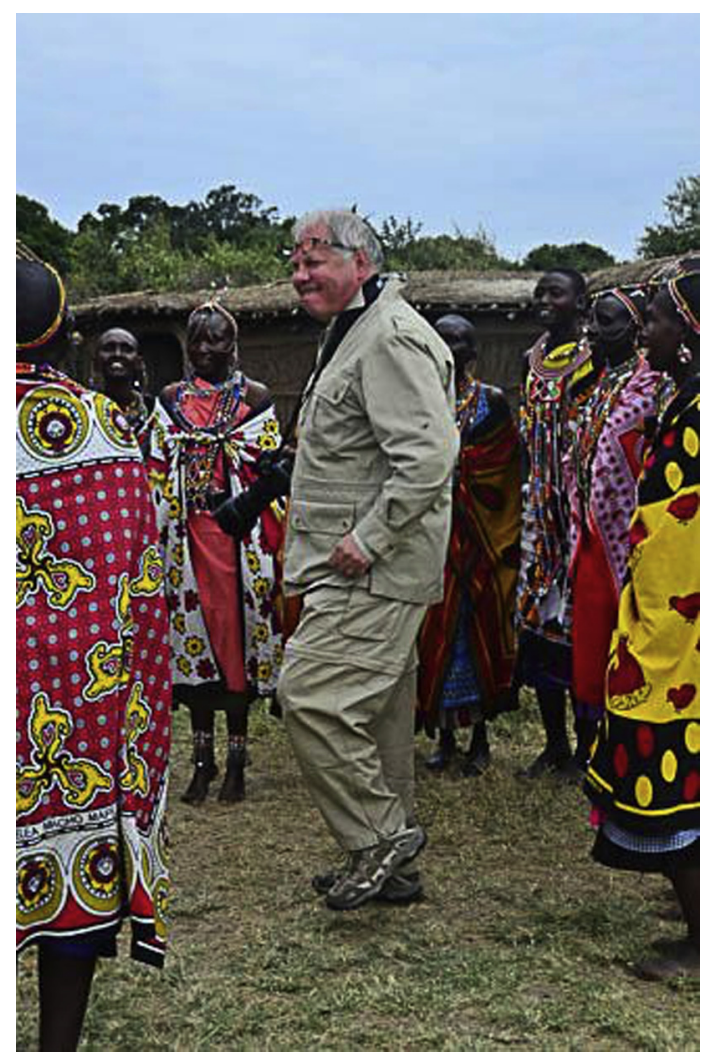

FIGURE 1. Dr Chitwood showcasing his exotic dance moves in Kenya.
After finishing his surgical residency at Duke, Ranny went to East Carolina University in Greenville, NC, to build and head a new Department of Cardiac Surgery. At the time, major academic cardiac surgery programs in North Carolina already existed at Duke University in Durham, University of North Carolina in Chapel Hill, and Bowman-Gray in Winston-Salem. In addition, large and historically successful private practice groups were thriving in Raleigh, Greensboro, Asheville, and Charlotte, among others. Ranny's peers usually conjured up the image of Don Quixote when he openly and confidently described his East Carolina University goals to us long before he had attained them. I visited him at East Carolina University after he had been there for only a few months and he said, "Do you see those 2 big empty fields out there? I'm going to fill them with buildings, including a major heart center that will shock everybody in this state." Well, that's exactly what he did, and how he did it under the circumstances remains a mystery to all of us. But, nothing Ranny does surprises us anymore.

Except for a 2-year hiatus as the chief of cardiothoracic surgery at the University of Kentucky, Ranny spent his entire career at East Carolina University in Greenville, NC. He served as chairman of the Department of Surgery there from 1995 to 2003. In July 2003, he was promoted

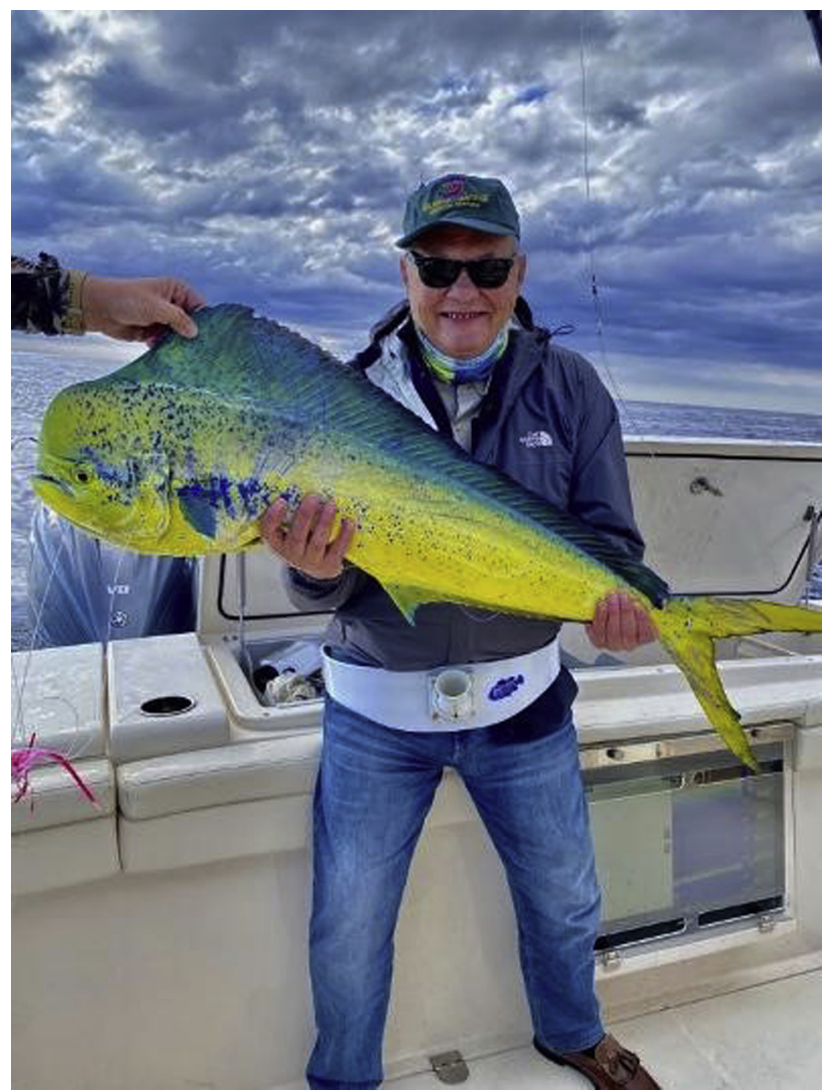

FIGURE 2. Well OK, perhaps he really is a great fisherman, too! 
to senior associate vice chancellor to be in charge of the development of a new specialty hospital and research institute: The East Carolina Heart Institute. In 2007, as founder and director of East Carolina Heart Institute, he was named the Eddie and Jo Allison Smith Distinguished Chair. The institute now includes an integrated Department of Cardiovascular Sciences as well as a heart hospital, outpatient, research, and education center. He performed the first robotic mitral valve operation in the United States and also in 12 other countries and the Robotic Surgical Center at East Carolina University has now trained more than 450 surgeons worldwide. In 2017, the W. Randolph Chitwood Distinguished Chair of Surgery was established in the Department of Cardiovascular Sciences, which he founded. Clinically, he was very active, having performed more than 10,000 cardiac operations during his career.

Dr Chitwood is a member of 25 professional societies, including the American College of Surgeons, the Royal College of Surgeons of England, the AATS, the STS, the Southern Thoracic Surgical Association, the Society of University Surgeons, the American Surgical Association, the American College of Cardiology, and the Cardiac Surgery Biology Club. He is a past-president of the STS, the International Society of Minimally Invasive Cardiothoracic Surgery, the International Society for Heart Valve Disease, and the North Carolina Chapter of the American Heart Association. Dr Chitwood has either served or presently serves on the editorial boards of Annals of Thoracic Surgery, Journal of Cardiothoracic and Vascular Surgery, Journal of Cardiac Surgery, American Heart Journal, Journal of Heart Valve Disease, Asian Annals of Cardiovascular and Thoracic Surgery, CTS Net, Chest, American Heart Journal, and Journal of Robotic Surgery. He has authored more than 250 peer reviewed scientific and clinical articles, as well as many book chapters and several monographs. He has given more than 60 invited lectures and has published the Atlas of Robotic Cardiac Surgery.

In 2003, Dr Chitwood was elected to Fellowship in the Royal College of Surgeons of England and during 2007 was a Hunterian Professor there. He is also an honorary member of the of the German Society for Thoracic and Cardiovascular Surgery, the Australian and New Zealand Society of Cardiac and Thoracic Surgeons, and the Society for Cardiothoracic Surgery in Great Britain and Ireland. In 2004, he received the O. Max Gardner Award from the University of North Carolina Board of Governors that recognizes a faculty member from the 16 constituent campuses who during the scholastic year made the greatest contribution to the "welfare of the human race." In 2005, he received the National Mended Hearts-Harken Award, which recognizes excellence in the field of cardiovascular medicine. during the same year, he received the National Phi Kappa Phi Scholar Award for outstanding teaching, research, practice, and service. In 2005, he was awarded an honorary
Doctor of Sciences degree from his undergraduate college Hampden-Sydney. In 2009 he received the Ellis Island Medal of Honor at Ellis Island for contributions to the health and welfare of diverse populations nationally and internationally. In 2012, he was awarded the Bakoulev Premium Medal from the Russian Academy of Medical Sciences and the Bakoulev Scientific Center for Cardiovascular Surgery for his work in minimally invasive cardiac procedures. Previously, he had been awarded the Burakovsky Medal from the same organization. In May 2015, he received the AATS Mitral Conclave Career Achievement Award for his accomplishments in the field of mitral valve surgery. Ranny remains active in our field through his current interests in the development of innovative lessinvasive heart valves and robotic surgical devices as well as heart center program development and teaching surgeon's safe patient application of new technology.

The last time I visited Ranny at East Carolina University we stood together at the same window we had peered through way back in 1985 . We were looking at the 2 previously empty fields that were now filled with several huge, beautiful modern buildings that were there primarily because of Ranny Chitwood's dreams. The fulfillment of those dreams had required a master administrator, a superb clinical surgeon, an innovative thinker, a productive researcher, a talented educator, a people person, and a natural leader. That is the very definition of Ranny Chitwood. I can personally confirm his talents outside medicine-except for the bit about his being a great fisherman - and I can even speak to that claim. In 2011, the Chitwoods and several other families invited me for a week of trout fishing in Montana. What I can vouch for is that Ranny's lovely wife of 50 years, Tammy, caught more fish than Ranny did and never once claimed to be a better fisherman! Tammy was the love of Ranny's life and was dear to every surgical resident who trained at Duke for generations. Her courage and bravery were on full display for months on end in 2018 until she finally succumbed to cancer in December of that year. All of us felt that as great as Ranny is, nobody was good enough to actually deserve Tammy, not even Ranny. He and Tammy raised 2 children, Randolph and Anne, 2 of the most interesting and accomplished people I know.

In closing, I would add that whether 1 believes that he is really a great fisherman or not, there is no arguing that $\mathrm{W}$. Randolph Chitwood, Jr, is a true Renaissance man. Many consider him to be the father of robotic mitral valve surgery and few would argue that he deserves that distinction. One of the great pleasures and honors in my life has been knowing him, training with him, and being his longtime friend. Thus, it was a special and distinct honor to be invited by Editor Richard Weisel to formally acknowledge Dr Chitwood as the 2020 recipient of the Scientific Achievement Award from the AATS. No person has ever deserved this award more than Ranny Chitwood. 